\title{
Paweł Kubicki
}

\section{Środowiska osób z niepełnosprawnościami wobec polityki publicznej - studia przypadków ${ }^{1}$}

\begin{abstract}
Streszczenie
Autor przedstawia trzy sytuacje pokazujące uczestnictwo osób z niepełnosprawnościami, opiekunów takich osób i stowarzyszeń działających na ich rzecz w kreowaniu i monitorowaniu polityki publicznej wobec niepełnosprawności w Polsce. Pierwsza z nich dotyczy działania polegającego na wspieraniu edukacji włączającej, druga - prób zmiany systemu wsparcia opiekunów osób z niepełnosprawnościami, natomiast ostatnia odnosi się do procesu tworzenia przez organizacje pozarządowe alternatywnego raportu poświęconego wdrażaniu przez Polskę konwencji ONZ o prawach osób niepełnosprawnych. W każdym z powyższych przypadków autor omawia przyczyny stojące za decyzją o zaangażowaniu się, przebieg procesu oraz efekty zaangażowania. Wnioski wskazują na to, że choć środowiska osób z niepełnosprawnościami mają możliwość wzięcia udziału w dyskusji na temat polityki wobec niepełnosprawności, to ich wpływ jest raczej niewielki i dotyczy sytuacji wyjątkowych.
\end{abstract}

Słowa kluczowe: polityka publiczna, polityka społeczna, niepełnosprawność, osoby z niepełnosprawnościami, edukacja włączająca, opieka długoterminowa.

\section{The groups of people with disabilities within the scope of public policy - case studies ${ }^{2}$}

\begin{abstract}
The author presents three selected types of situations depicting the participation of persons with disabilities, their caregivers and supporting non-governmental organisations,

1 Niniejszy tekst stanowi fragment przygotowywanej rozprawy habilitacyjnej poświęconej polityce publicznej wobec niepełnosprawności.

2 The following paper constitutes a part of the post doc dissertation addressing the issue of public policy in the area of disabilities.
\end{abstract}


in designing and monitoring the public policy towards disability in Poland. The first type of situations concerns supporting inclusive education. The second type concerns the support system for the caregivers of the persons with disabilities, while the last one refers to the alternative report prepared by NGOs, dealing with Poland's implementation of the U.N. Convention on the Rights of Persons with Disabilities. In each of these cases, the author examines the reasons behind the decision to participate, the process, and the final results of participation. The results show that - although the NGOs of the persons with disabilities have the possibility to participate in the discussion on disability policy - their influence on that policy is insignificant and limited to exceptional situations.

Keywords: public policy, social policy, disability, persons with disabilities, inclusive education, long-term care.

Konwencja ONZ o prawach osób niepełnosprawnych ${ }^{3}$ (KPON) zakłada, że jednym z kluczowych aktorów/interesariuszy tworzących politykę publiczną w zakresie niepełnosprawności powinni być obywatele - działający czy to w sposób sformalizowany poprzez organizacje pozarządowe, czy też jako niesformalizowane grupy. W art. 4 pkt 3 KPON czytamy: „(...) przy tworzeniu i wdrażaniu ustawodawstwa i polityki celem wprowadzenia w życie niniejszej konwencji, a także w toku podejmowania decyzji w zakresie spraw dotyczących osób niepełnosprawnych Państwa Strony będą ściśle konsultować się z osobami niepełnosprawnymi, a także angażować te osoby, w tym niepełnosprawne dzieci, w te procesy, za pośrednictwem reprezentujących je organizacji”.

Kwestia zaangażowania obywateli i działających na ich rzecz organizacji pozarządowych w kreowanie agendy, a także późniejsze wdrażanie polityki publicznej są relatywnie dobrze opisane w literaturze przedmiotu ${ }^{4}$. Jednocześnie dyskusja o roli aktorów społecznych dotyczy również nowego spojrzenia na rządzenie (ang. governence) jako proces wielosektorowy czy wielowymiarowy (ang. multi-level governance) i w coraz większym stopniu zdecentralizowany5. O ile jednak ogólne mechanizmy samego zaangażowania w proces strony społecznej i przyczyn stojących za wzrastającą rolą obywateli, a przynajmniej postulatami na rzecz wzrostu znaczenia społeczeństwa,

3 Konwencja o prawach osób niepełnosprawnych z dnia 13 grudnia 2006 r., Dz. U z 2012 r. poz. 1169.

4 Zob. np. A. Zybała, Polityki publiczne: doświadczenia w tworzeniu i wykonywaniu programów publicznych w Polsce i w innych krajach. Jak działa państwo, gdy zamierza (chce) musi rozwiązać zbiorowe problemy swoich obywateli?, Krajowa Szkoła Administracji Publicznej, Warszawa 2012; a w kontekście niepełnosprawności: L. Vanhala, Making Rights a Reality?: Disability Rights Activists and Legal Mobilization, Cambridge University Press, Cambridge 2014.

5 Zob. np. M. Grewiński, Wielosektorowa polityka społeczna: o przeobrażeniach państwa opiekuńczego, Wydawnictwo Wyższej Szkoły Pedagogicznej TWP, Warszawa 2009; P. Cairney, Understanding public policy: theories and issues, Palgrave Macmillan, New York 2012, s. 154-174; M. Howlett, Designing public policies: principles and instruments, Routledge, New York 2011, s. 125-138. 
są dosyć dobrze znane, o tyle poza pojedynczymi przypadkami opis ten nie odnosi się do sytuacji osób z niepełnosprawnościami w Polsce ${ }^{6}$.

W poniższym tekście staram się uzupełnić tę lukę i pokazać na wybranych przykładach, jak takie zaangażowanie może wyglądać w praktyce, przy czym interesują mnie zarówno powody zaangażowania się umownie rozumianej strony społecznej, reakcje instytucji publicznych, jak i efekty współpracy czy też - przyjmując nieco inne rozróżnienie zaproponowane w jednym $z$ opracowań ${ }^{7}$ - to, jaka jest rola obywateli w systemie tworzenia polityki, jej doskonalenia i monitorowania oraz realizacji.

W opracowaniu przyjmuję definicję polityki publicznej jako „zracjonalizowane działania i programy publiczne, które oparte są na zgromadzonej, względnie zobiektywizowanej wiedzy i usystematyzowanym procesie projektowania i wykonywania

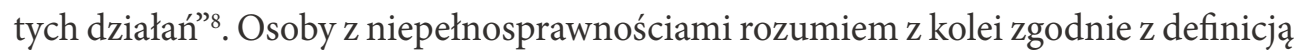
zawartą w art. $1 \mathrm{KPON}$, według której są to osoby mające długotrwale naruszoną sprawność fizyczną, psychiczną ${ }^{9}$, intelektualną lub w zakresie zmysłów, co może w oddziaływaniu z różnymi barierami utrudniać im pełny i skuteczny udział w życiu społecznym na zasadzie równości z innymi osobami.

W badaniach wykorzystałem metodologię badań w działaniu (ang. participatory action research), dobór przypadków jest związany z moim współuczestnictwem w każdym z opisywanych wydarzeń, a osobiste refleksje są uzupełnione o analizę dokumentów zastanych.

\section{Dodatkowe wagi subwencyjne z tytułu niepełnosprawności}

Pierwszy przypadek partycypacji, który chcę opisać, dotyczy walki z barierami, które ograniczają realizację idei edukacji włączającej ${ }^{10}$. Rozumiem ją w pewnym

6 Wpływ ruchu rodziców osób z niepełnosprawnością intelektualna na rozwój nauki i życie społeczne: raport z badań, red. B. Abramowska, Polskie Stowarzyszenie na rzecz Osób z Upośledzeniem Umysłowym, Warszawa 2014; R. Bakalarczyk, Polityka wsparcia rodzin z osobami niepełnosprawnymi. W cieniu wyroków Trybunału Konstytucyjnego RP i protestów społecznych, „Studia z Polityki Publicznej” 2015, nr 1(5), s. 63-80.

7 R. Szarfenberg, Potrzeba udziału obywateli w tworzeniu, realizacji i doskonaleniu polityki społecznej, Konferencja EAPN „Partycypacja obywatelska w tworzeniu usług społecznych”, Warszawa, 15 stycznia 2016.

8 A. Zybała, op.cit., s. 24.

9 W oryginalnym polskim tłumaczeniu angielski termin mental przetłumaczono błędnie jako niepełnosprawność umysłową, a nie psychiczną, co czyni niejasnym rozróżnienie na niepełnosprawność umysłową i intelektualną. K. Kurowski, Wolności i prawa człowieka i obywatela z perspektywy osób z niepetnosprawnościami, Biuro Rzecznika Praw Obywatelskich, Warszawa 2014, s. 18.

${ }^{10}$ D. Al-Khamisy, Edukacja włączajaca edukacją dialogu: w poszukiwaniu modelu edukacji dla ucznia ze specjalnymi potrzebami edukacyjnymi, Wydawnictwo Akademii Pedagogiki Specjalnej, Warszawa 2013; 
uproszczeniu jako umożliwienie edukacji uczniom o specjalnych potrzebach edukacyjnych - nie tylko uczniów z niepełnosprawnościami - w swoim środowisku rówieśniczym i na równych prawach. Jedną z ważniejszych barier stanowią wynikające ze wspomnianych specjalnych potrzeb podwyższone koszty edukacyjne, na które szkoły ogólnodostępne często nie otrzymywały dodatkowych środków.

Problem ten był dostrzegany dość wcześnie przez praktyków, ale został opisany po raz pierwszy w 2009 r. w ramach projektu „Wszystko jasne. Dostępność i jakość edukacji dla uczniów z niepełnosprawnościami" ${ }^{11}$. Realizowało go Stowarzyszenie Pomocy Dzieciom z Ukrytymi Niepełnosprawnościami im. Hansa Aspergera „Nie-Grzeczne Dzieci", a finansowała Fundacja im. Stefana Batorego w ramach programu „Działania strażnicze” oraz w ramach kolejnych grantów, aż do czerwca $2016 \mathrm{r}$. Powodem zajęcia się sprawą były osobiste doświadczenia rodziców dzieci z niepełnosprawnościami z Warszawy.

Zanim opiszę perypetie związane z partycypacją, chcę wyjaśnić problemy dotyczące systemu finansowania oświaty. W Polsce najczęściej następuje ono za pomocą subwencji oświatowej, a poprawnie: części oświatowej subwencji ogólnej, naliczanej dla każdej jednostki samorządu terytorialnego na podstawie algorytmu. Można go znaleźć w corocznym rozporządzeniu Ministra Edukacji Narodowej w sprawie sposobu podziału części oświatowej subwencji ogólnej na dany rok budżetowy. Warto podkreślić fakt, iż żaden z przepisów nie wskazuje na to, że subwencja $\mathrm{z}$ budżetu państwa ma pokrywać w całości wydatki oświatowe jednostek samorządu terytorialnego. Stanowi ona jedno ze źródeł finansowania tych zadań obok innych dochodów jednostek samorządu terytorialnego, w szczególności dochodów własnych ${ }^{12}$. Na ucznia niepełnosprawnego kwota subwencji jest uzupełniona o dodatkową kwotę, wynikającą z rodzaju niepełnosprawności: stanowi wielokrotność stawki bazowej na ucznia (mnożnik wynosi od 1,4 do 9,5). Owa kwota uzupełniająca, zwana wagą przeliczeniową, jest naliczana na potrzeby samorządu na podstawie orzeczenia o specjalnych potrzebach edukacyjnych wydanego przez poradnię psychologiczno-pedagogiczną ze

P. Kubicki, Równy dostęp do edukacji osób z niepetnosprawnościami, „Biuletyn RPO. Źródła” 2012, nr 10, s. 34-40; P. Kubicki, Prawne bariery edukacji właczającej, „Studia Prawnicze” 2013, z. 2(194), s. 63-77.

${ }_{11}$ A. Dudzińska, Wszystko jasne. Dostępność i jakość edukacji dla uczniów z niepetnosprawnościami. Raport końcowy z realizacji projektu, Stowarzyszenie Pomocy Dzieciom z Ukrytymi Niepełnosprawnościami im. Hansa Aspergera „Nie-Grzeczne Dzieci”, Warszawa 2009.

12 Odpowiedź Macieja Jakubowskiego, podsekretarza stanu w Ministerstwie Edukacji Narodowej, na interpelacje $\mathrm{nr} 18740 \mathrm{w}$ sprawie finansowania przez samorzady działalności małych szkół wiejskich, http://www.sejm.gov.pl/sejm7.nsf/InterpelacjaTresc.xsp?key=66D13F5C, dostęp 21.10.2015. O zakresie, sposobie i źródle finansowania zadań oświatowych przesądzają przepisy art. 5a ust. 3 ustawy z dnia 7 września 1991 r. o systemie oświaty (Dz. U. z 2004 r. Nr 256, poz. 2572, z późn. zm.), w myśl których środki niezbędne do realizacji zadań oświatowych, $\mathrm{w}$ tym na wynagrodzenia nauczycieli oraz utrzymanie szkół i placówek, są zagwarantowane w dochodach JST. 
względu na niepełnosprawność. Zgodnie z intencją ustawodawcy środki te są przeznaczone na pokrycie specjalnych potrzeb edukacyjnych ucznia, formalnie jednak związek ten nie istniał, samorządy bowiem mogą wydawać subwencję na dowolny cel, a w praktyce często przeznaczały ją na stałe koszty funkcjonowania oświaty jako takiej, a nie na specjalne potrzeby konkretnych dzieci. Warto dodać, że ze względu na brak wydzielania tych środków $z$ budżetu oświatowego jednostki samorządu terytorialnego oraz arkuszy sprawozdawczych poszczególnych szkół nie istniała także możliwość zweryfikowania sposobu wydatkowania. Z powyższych powodów powstał pomysł, aby powiązać dodatkową wagę subwencyjną ze szkołą, do której chodzi uczeń $\mathrm{z}$ niepełnosprawnością, poprzez zamianę dodatkowych wag subwencyjnych wynikających z niepełnosprawności z subwencji w dotację, która wymaga wydatkowania przyznanych środków zgodnie z celem i dokładnej sprawozdawczości.

Poniżej przedstawiam w punktach poszczególne elementy procesu formułowania problemu, który stał się przedmiotem projektu:

- 2008 r. - identyfikacja problemów w szkole ogólnodostępnej z zapewnieniem uczniom odpowiedniego wsparcia, współpraca $z$ innymi rodzicami, nieudane próby rozwiązania sytuacji na własną rękę;

- 2009 r. - rozpoczęcie projektu, badania ilościowe na terenie Warszawy, które pokazały, że problem nie jest jednostkowy; próba przekonania władz miasta i Ministerstwa Edukacji Narodowej (MEN) do zmiany polityki; publikacja raportu, który jednak nie zmienił sytuacji;

- 2010 r. - stagnacja, zawieszenie finansowania projektu, kontynuacja działalności na mniejszą skalę, brak widocznych efektów;

- 2011 r. - kolejny projekt, nowi współpracownicy, w tym autor niniejszego opracowania; stworzenie funkcji rzecznika uczniów niepełnosprawnych; realizacja badań jakościowych dotyczących sytuacji uczniów i rodziców; rozszerzenie działania na Polskę, uczestnictwo w komisjach sejmowych; złożenie - przy pomocy posłów Prawa i Sprawiedliwości - projektu ustawy o zmianie ustawy o systemie oświaty dotyczącego zmiany mechanizmu podziału środków przekazywanych na prowadzenie samorządowych jednostek budżetowych prowadzących działalność oświatową ${ }^{13}$; projekt nie został ostatecznie rozpatrzony w związku z końcem kadencji sejmu;

- 2012 r. - częściowe wycofanie się dotychczasowej liderki; kontynuacja działalności przez nowych współpracowników; zintensyfikowanie kontaktów z mediami,

${ }_{13}$ Poselski projekt ustawy o zmianie ustawy o systemie oświaty, http://orka.sejm.gov.pl/proc6.nsf/opisy/ 4474.htm, dostęp 22.10.2015. 
stworzenie informatora dla rodziców, nawiązanie stałej współpracy z Departamentem Zwiększania Szans Edukacyjnych MEN oraz Biurem Rzecznika Praw Obywatelskich;

- 2013 r. - kolejna zmiana osób prowadzących projekt po wycofaniu się autora niniejszego tekstu i objęciu przez niego funkcji eksperta przy realizacji projektu; kontynuacja dotychczasowych działań, aktualizacja informatora dla rodziców, aktywniejszy udział w konsultacjach społecznych poszczególnych aktów prawnych dotyczących edukacji, udział w Forum Rodziców przy MEN;

- 2014r. - jedna z matek prowadzących dotychczas projekt „Wszystko jasne” zaczyna współprowadzić w ramach Fundacji Instytut Rozwoju Regionalnego komplementarny projekt informacyjny dla rodziców ${ }^{14}$, finansowany ze środków Ministerstwa Pracy i Polityki Społecznej w ramach programu operacyjnego „Kapitał ludzki”; kontynuowanie działań zmierzających do zamiany subwencji w dotację, a także monitoringu jakości i dostępności edukacji dla uczniów z niepełnosprawnościami; w ramach nowego projektu zostaje dodatkowo podjęta kwestia godzenia przez rodziców ról zawodowych i opiekuńczych; powstaje - w ramach drugiego projektu - kolejny informator dla rodziców, obejmujący poza kwestiami edukacyjnymi zagadnienia związane z pomocą społeczną, służbą zdrowia i rynkiem pracy; w wyniku działalności lobbingowej powstaje art. 32 ustawy z dnia 5 grudnia 2014 r. o zmianie niektórych ustaw w związku z realizacją ustawy budżetowej (Dz. U. z 2014 r. poz. 1877), nakazuje on samorządom rozliczenie się ze środków z subwencji naliczanych na uczniów z niepełnosprawnościami; rozliczenie to jest jednak dokonywane na poziomie wszystkich szkół prowadzonych przez dany organ, czyli nie ma konieczności przekazania ich do konkretnej szkoły ${ }^{15}$;

- 2015 r. - kontynuacja działań w obu projektach, dalsze prace na rzecz zamiany subwencji w dotację, zwieńczone przedłużeniem rozwiązania zastosowanego w 2015 r. w ramach art. 13 ustawy z dnia 16 grudnia 2015 r. o szczególnych rozwiązaniach służących realizacji ustawy budżetowej na rok 2016 (Dz. U. z 2015 r. poz. 2199) ${ }^{16}$.

W ramach projekt osiągnięto dalsze sukcesy. W czasie jego trwania kilka tysięcy rodziców dzieci z niepełnosprawnościami, jak również nauczycieli i przedstawicieli władz samorządowych zapoznało się z informacjami na temat rozwiązań prawnych

${ }^{14}$ O projekcie, http://www.pomocdlarodzicow.pl/o-projekcie, dostęp 22.10.2015.

15 Zob. Ustawa okołobudżetowa na 2015 r. i subwencja oświatowa, http://wszystkojasne.waw.pl/ustawaokolobudzetowa-na-2015-r-subwencja-oswiatowa, dostęp 22.10.2015; Art. 32 ustawy okołobudżetowej, http://www.forum.jst.vulcan.edu.pl/zoswiatap_files/user/ART\%2032\%20USTAWY.pdf, dostęp 22.10.2015.

${ }_{16}$ Zob. List do Ministra Finansów w sprawie art. 13 ustawy okołobudżetowej na 2016, http://cbnn.pl/ list-do-ministra-finansow-w-sprawie-art-13-ustawy-okolobudzetowej-na-2016, dostęp 05.01.2016. 
oraz praktyki edukacyjnej. Kolejnym sukcesem było nagłośnienie w mediach problematyki przekazywania środków na edukację uczniów ze specjalnymi potrzebami edukacyjnymi i przy okazji zasad finansowania oświaty. Ponadto, doszło do konsultacji kilkunastu aktów prawnych dotyczących kształcenia specjalnego, $\mathrm{w}$ tym przede wszystkim rozporządzeń doprecyzowujących politykę oświatową.

Patrząc na chronologię wydarzeń, warto zauważyć, że rozpoczęcie całego procesu wynikało nie tyle z pojawienia się problemu związanego z edukacją, ile z braku reakcji ze strony instytucji publicznych na jego zgłoszenie. To bierność instytucji uprawnionych do działania wymusiła aktywność społeczną.

Kolejnym punktem zwrotnym w funkcjonowaniu projektu była rekrutacja nowych współpracowników i rozszerzenie działalności na cały kraj, tzn. rozszerzenie monitoringu i poradnictwa na teren całej Polski, oraz podjęcie stałej współpracy $\mathrm{z}$ mediami i instytucjami zewnętrznymi, a także z podmiotem posiadającym realną moc sprawczą, czyli Ministerstwem Edukacji Narodowej. Impulsem do rozpoczęcia działalności ogólnokrajowej, czego skutkiem było ograniczenie uczestnictwa w posiedzeniach poszczególnych komisji Rady Warszawy na rzecz sejmowych Komisji Edukacji, Nauki i Młodzieży oraz Komisji Polityki Społecznej i Rodziny, była konstatacja, że problem nie jest rozwiązywalny na poziomie lokalnym, ma on bowiem podłoże systemowe i wynika $\mathrm{z}$ rozwiązań legislacyjnych na poziomie ustawowym. Natomiast współpraca z mediami pozwalała przede wszystkim nagłośnić problem, a tym samym wpłynąć na agendę.

Główne ryzyko obecne przez cały okres trwania projektu wiązało się przede wszystkim z jego akcyjnością i coroczną niepewnością dotyczącą tego, czy znajdą się środki na jego finansowanie. Jednocześnie, choć nie udało się zrealizować w pełni początkowego postulatu, mówiącego o zamianie subwencji w dotację, to w latach 2015 i 2016 można mówić o ograniczonym sukcesie całej akcji, z jednej strony bowiem powstała ustawa okołobudżetowa mówiąca o konieczności rozliczania się ze środków naliczanych na niepełnosprawność, a z drugiej - powszechnie uznano sposób finansowania uczniów z niepełnosprawnościami za problem wymagający rozwiązań systemowych ${ }^{17}$. W ramach wewnętrznych dyskusji zespołu projektowego jako kluczowe elementy przyczyniające się do tego sukcesu wskazano:

- jasne zdefiniowanie problemu oraz zebranie danych ilościowych i jakościowych pozwalających na jego uwiarygodnienie;

${ }_{17}$ Zob. np. informacja MRPiPS z 3 grudnia 2015 r. w tej sprawie: Środki na edukację dzieci niepełnosprawnych, https://www.mpips.gov.pl/aktualnosci-wszystkie/art,5528,7525, srodki-na-edukacje-dzieci-niepelnosprawnych.html, dostęp 26.02.2016. 
- długotrwałość działań i ich kontynuowanie w kolejnych latach mimo braku większych sukcesów;

- nawiązanie współpracy z mediami, pozwalające na nagłośnienie problemu, a tym samym zwiększenie jego wagi;

- współpracę z Rzecznikiem Praw Obywatelskich (RPO) oraz innymi organizacjami pozarządowymi, ale też wspieranie rodziców, czyli szukanie sojuszników i zwolenników, by uniknąć pozostania samym z problemem;

- współpracę z parlamentarzystami oraz rządem, czyli kreatorami polityki publicznej. Na marginesie warto też dodać, że jednym z istotnych elementów ułatwiających przetrwanie projektu było jego finansowanie przez Fundację im. Stefana Batorego ze środków amerykańskich. Pozwalało to na większą elastyczność w dysponowaniu budżetem, niż ma to miejsce w typowych projektach unijnych, i dostosowanie wydatków do nowych potrzeb. Takim przykładem przesunięcia wydatków było np. wydanie poradnika dla rodziców, który początkowo nie był planowany, ale powstał w odpowiedzi na zapotrzebowanie rodziców i ze względu na powtarzalność problemów zgłaszanych przez osoby z różnych stron Polski.

\section{Opiekunowie osób z niepełnosprawnościami i tzw. okrągły stół ds. osób niepełnosprawnych}

Poniżej chcę opisać najnowszy przypadek „otwarcia systemu”"18, w wyniku czego część obywateli uzyskała realny wpływ na proces kreowania polityki publicznej wobec niepełnosprawności. Chodzi tu o protest opiekunów dzieci z niepełnosprawnościami. Jego najbardziej medialnym momentem był strajk okupacyjny. Doszło do niego, ponieważ część protestujących przeciwko obowiązującym rozwiązaniom prawnym rodziców postanowiła zostać w budynku Sejmu RP po konferencji prasowej zorganizowanej 19 marca 2014 r. na jego terenie. Trwałym efektem tego protestu było zwiększenie wysokości świadczeń pielęgnacyjnych dla opiekunów dzieci i osób, których niepełnosprawność wystąpiła przed 18 lub 25 - w przypadku osób kontynuujących naukę - rokiem życia, co zagwarantowała ustawa z dnia 24 kwietnia 2014 r. o zmianie ustawy o świadczeniach rodzinnych (Dz. U. z 2014 r. poz. 559).

Warto jednak trochę dłużej zatrzymać się zarówno nad tym, co doprowadziło do samej okupacji, jak i nad dalszymi konsekwencjami tego protestu. Należy bowiem pamiętać, że sama okupacja była zwieńczeniem znacznie dłuższego i niezbyt

18 A. Kloskowska-Dudzińska, System zamknięty: socjologiczna analiza procesu legislacyjnego, Wydawnictwo Naukowe Scholar, Instytut Studiów Politycznych Polskiej Akademii Nauk, Warszawa 2015. 
owocnego dialogu z rządem, nie tylko opiekunów dzieci, ale także dorosłych osób z niepełnosprawnościami ${ }^{19}$. Pokłosiem protestu były też obrady tzw. okrągłego stołu, którego prace dotyczyły tego, jak wspierać osoby niepełnosprawne, i którego pierwsze posiedzenie odbyło się 30 kwietnia $2014 \mathrm{r}^{20}$ Spotkania te były kontynuowane przez kilka miesięcy w trakcie prac tzw. podstolików, ale zakończyła je strona rządowa bez podjęcia wiążących decyzji.

Co sprawiło, że wcześniejsze spotkania ze stroną rządową nie przyniosły rezultatów, a część opiekunów osób dorosłych do chwili pisania tego tekstu (luty 2016 r.) nie doczekała się równie korzystnych co opiekunowie dzieci rozwiązań? ${ }^{21}$ Równocześnie, co często umyka w dyskusji, strona społeczna nie doczekała się realizacji żadnego z pozostałych swoich postulatów ${ }^{22}$. Dlaczego wcześniej na stronach Ministerstwa Pracy i Polityki Społecznej, a obecnie już Ministerstwa Rodziny, Pracy i Polityki Społecznej nie można znaleźć żadnych informacji o toczących się przez prawie rok spotkaniach w ramach tzw. podstolików? Wreszcie, jakie kluczowe momenty negocjacji strony społecznej ze stroną rządową można wskazać?

Spójrzmy na chronologię zmian w systemie wsparcia materialnego opiekunów osób niepełnosprawnych zaprezentowaną przez R. Bakalarczyka ${ }^{23}$. Otóż można podzielić ją - zgodnie z perspektywą przyjętą przez autora, odwołującą się do opiekunów osób dorosłych i starszych - na sześć etapów:

- I (2003-2008) - opiekunowie osób starszych poza systemem świadczeń pieniężnych;

- II (2008-2009) - ubożsi opiekunowie osób starszych nabywają prawo do świadczeń;

- III (2010-2012) - wszyscy całkowicie rezygnujący z pracy opiekunowie osób starszych nabywają prawo do świadczenia;

- IV (2013) - podział opiekunów i pojawienie się grupy tzw. wykluczonych opiekunów;

${ }_{19}$ R. Bakalarczyk, P. Kubicki, M. Polakowski, D. Szelewa, Niepetnosprawność: problemy opieki. Warszawskie debaty o polityce społecznej 15, Friedrich-Ebert-Stiftung, Przedstawicielstwo w Polsce wspólnie z Fundacją Międzynarodowe Centrum Badań i Analiz (ICRA), Warszawa 2015; R. Bakalarczyk, op.cit. Zobacz również wpisy na blogu R. Bakalarczyka, który towarzyszył protestującym opiekunom osób dorosłych: http://lewica.pl/blog/bakalarczyk, dostęp 21.10.2015.

20 Zob. transmisja z pierwszego posiedzenia: Jak wspierać osoby niepetnosprawne? - wideo i stenogram z okragłego stołu, http://www.mpips.gov.pl/aktualnosci-wszystkie/swiadczenia-rodzinne/art,6709, jak-wspierac-osoby-niepelnosprawne-wideo-i-stenogram-z-okraglego-stolu.html, dostęp 21.10.2015.

${ }^{21}$ Zob. wycofany w I kwartale 2015 r. projekt nowelizacji: Projekt ustawy o zmianie ustawy o świadczeniach rodzinnych, http://bip.kprm.gov.pl/kpr/wykaz/r1017,Projekt-ustawy-o-zmianie-ustawy-oswiadczeniach-rodzinnych.html, dostęp 21.10.2015.

22 Zob. Notatka ze spotkania $w$ dniu 16.02.2016 z przedstawicielami Ministerstwa Rodziny Pracy i Polityki Społecznej, https://www.facebook.com/notes/ron-rodzice-os\%C3\%B3b-niepe\%C5\%82nosprawnych/notatka-ze-spotkania-w-dniu-16022016-z-przedstawicielami-ministerstwa-rodziny-pr/956567307759749, dostęp 19.02.2016.

${ }_{23}$ R. Bakalarczyk, op.cit., s. 71-73. 
- V (2014) - przygotowanie i przyjęcie ustawy o wypłacie zasiłku dla opiekuna;

- VI (od 2015) - w stronę świadczenia pielęgnacyjnego dla opiekunów bez względu na wiek podopiecznego.

Przedstawienie obecnej sytuacji prawnej znajduje się natomiast w poniższej tabeli.

Tabela 1. Świadczenia opiekuńcze (stan prawny na luty 2016 r.) i w projekcie MPiPS

\begin{tabular}{|c|c|c|c|c|}
\hline & $\begin{array}{l}\text { Świadczenie } \\
\text { pielęgnacyjne }\end{array}$ & $\begin{array}{l}\text { Specjalny zasiłek } \\
\text { opiekuńczy }\end{array}$ & $\begin{array}{l}\text { Zasiłek dla } \\
\text { opiekuna }\end{array}$ & $\begin{array}{l}\text { Świadczenie pielęgnacyjne } \\
\text { (projekt z marca 2015 r.) }\end{array}$ \\
\hline $\begin{array}{l}\text { Wysokość } \\
\text { wsparcia }\end{array}$ & 1300 PLN & 520 PLN & 520 PLN & $\begin{array}{l}\text { 800 PLN (dla opiekunów } \\
\text { osób dorosłych) i 1200 PLN } \\
\text { (dla opiekunów dzieci) }\end{array}$ \\
\hline $\begin{array}{l}\text { Kryterium } \\
\text { dochodowe }\end{array}$ & brak & 664 PLN netto & brak & 1000 PLN netto na osobę \\
\hline $\begin{array}{l}\text { Kryterium wieku } \\
\text { podopiecznego }\end{array}$ & $\begin{array}{l}\text { niepełnosprawność } \\
\text { przed } 18 \text { lub } 25 \text { rokiem } \\
\text { życia w przypadku } \\
\text { kontynuacji nauki }\end{array}$ & \multicolumn{2}{|c|}{$\begin{array}{l}\text { niepełnosprawność powstała } \\
\text { w okresie dorosłości }\end{array}$} & $\begin{array}{l}\text { bez względu na wiek powstania } \\
\text { niepełnosprawności }\end{array}$ \\
\hline $\begin{array}{l}\text { Kryteria } \\
\text { po stronie } \\
\text { opiekuna }\end{array}$ & \multicolumn{3}{|c|}{$\begin{array}{l}\text { całkowita rezygnacja z pracy; niepobieranie świadczeń } \\
\text { emerytalno-rentowych; obowiązek alimentacyjny wobec } \\
\text { podopiecznego }\end{array}$} & $\begin{array}{l}\text { jak poprzednio z ograniczeniami } \\
\text { w obrębie obowiązku } \\
\text { alimentacyjnego, pewne } \\
\text { uprawnianie dla osób } \\
\text { otrzymujących świadczenia } \\
\text { emerytalno-rentowe }\end{array}$ \\
\hline
\end{tabular}

Źródło: R. Bakalarczyk, P. Kubicki, M. Polakowski, D. Szelewa, Niepełnosprawność: problemy opieki. Warszawskie debaty o polityce społecznej 15, Friedrich-Ebert-Stiftung, Przedstawicielstwo w Polsce wspólnie z Fundacją Międzynarodowe Centrum Badań i Analiz (ICRA), Warszawa 2015, s. 16.

Wydaje się, że katalizatorem protestów było tutaj cofnięcie części przywilejów - przede wszystkim ze względu na rosnące wydatki budżetowe na świadczenia - ustawą z dnia 7 grudnia 2012 r. o zmianie ustawy o świadczeniach rodzinnych oraz niektórych innych ustaw (Dz. U. z 2012 r. poz. 1548). Należy przy okazji wspomnieć, że wcześniejsze zwiększenie liczby uprawnionych jest w jakimś stopniu efektem wyroków Trybunału Konstytucyjnego (TK) z 2008 r. ${ }^{24}$ Cofnięcie uprawnień wywołało zarówno protesty społeczne, jak i zainteresowanie medialne tematem opieki nad osobami z ograniczoną samodzielnością. Doszło też do spotkań ze stroną rządową, jednak nie przyniosły one większego efektu. Jednocześnie Rzecznik Praw Obywatelskich skierował do TK wniosek o zbadanie zgodności nowelizacji ustawy z 7 grudnia 2012 r. z konstytucją. W efekcie 5 grudnia 2013 r. TK orzekł, że art. 11 ust. 1 i 3 ustawy z dnia 7 grudnia 2012 r. o zmianie ustawy o świadczeniach rodzinnych oraz

24 Zob. informacja na stronach MRPiPS: Informacja dotycząca wyroków Trybunału Konstytucyjnego, http://www.mpips.gov.pl/aktualnosci-wszystkie/swiadczenia-rodzinne/art,4578, informacja-dotyczacawyrokow-trybunalu-konstytucyjnego.html, dostęp 19.01.2016. 
niektórych innych ustaw (Dz. U. z 2012 r. poz. 1548) jest niezgodny z art. 2 konstytu$\mathrm{cji}^{25}$. Zdynamizowało to protesty strony społecznej oraz dało przekonanie, że ustawa musi zostać zmieniona. Jednak kolejne spotkania nie przyniosły żadnych decyzji, a przełomem okazała się dopiero decyzja rodziców uczestniczących w konferencji prasowej zorganizowanej w dniu 19 marca 2014 r. przy wsparciu klubu poselskiego Solidarna Polska o pozostaniu na terenie Sejmu RP i rozpoczęciu strajku okupacyjnego.

Okupacja Sejmu wywołała ogromne zainteresowanie mediów, a także zdynamizowała prace rządu nad nowelizacją ustawy o świadczeniach rodzinnych. Co ciekawe, zorganizowany z kilkudniowym opóźnieniem podobny strajk okupacyjny opiekunów osób dorosłych z tożsamymi - jeśli chodzi o kwestię zwiększenia wysokości i sposobu przyznawania świadczenia pielęgnacyjnego - postulatami, ale już na skwerze przed budynkiem sejmowym spotkał się ze znacznie mniejszym zainteresowaniem medialnym i rządowym. Finalnie zresztą wszystkie postulaty protestujących przed Sejmem RP nie zostały spełnione do tej pory, a jedynym trwałym efektem obu protestów jest obiecana publicznie przed kamerami podwyżka świadczenia pielęgnacyjnego dla tzw. opiekunów dzieci. Takie prawne zróżnicowanie sytuacji opiekunów przypieczętowało rozbicie jedności całego środowiska, a tym samym możliwość wywierania znaczącego nacisku na stronę rządową ${ }^{26}$.

Obiecana i procedowana w bardzo szybkim tempie - prace legislacyjne zakończone już po miesiącu od protestu - podwyżka świadczenia pozwoliła na zakończenie okupacji Sejmu, a pozostałe obietnice miały zostać przedyskutowane i opracowane podczas prac tzw. okrągłego stołu ds. niepełnosprawności, którego pierwsze uroczyste posiedzenie odbyło się 30 kwietnia 2014 r. Jednocześnie było to ostatnie spotkanie na ten temat cieszące się zainteresowaniem mediów i traktowane priorytetowo przez rząd. Wszystkie późniejsze spotkania w poszczególnych grupach tematycznych nie doczekały się spójnego podsumowanie i nie były nagłaśniane przez stronę rządową, prace podkomisji zostały formalnie zawieszone, a faktycznie zakończone przed wakacjami w $2015 \mathrm{r}$.

Co ciekawe, tym razem, w przeciwieństwie do poprzednich przypadków, sytuacji nie zmienił kolejny wyrok TK z dnia 21 października 2014r., mówiący o tym, że zróżnicowanie prawa do świadczenia pielęgnacyjnego osób sprawujących opiekę nad

${ }_{25}$ Zob. wyrok TK wraz z uzasadnieniem: Świadczenie pielegnacyjne, http://trybunal.gov.pl/rozprawy-i-ogloszenia-orzeczen/wyroki/art/5696-swiadczenie-pielegnacyjne, dostęp 19.01.2016.

26 Zob. też strona liderów protestu sejmowego: Rodzice niepetnosprawnych dzieci w Sejmie. Walka trwa, https://www.facebook.com/Rodzice-niepe\%C5\%82nosprawnych-dzieci-w-Sejmie-Walka-trwa537913416328187, dostęp 10.01.2016; strony dwóch frakcji opiekunów osób dorosłych, które protestowały przed budynkiem: Wykluczeni Opiekunowie Dorosłych Osób Niepełnosprawnych, https://www. facebook.com/WODON, dostęp 10.01.2016; Opiekun Osoby Niepełnosprawnej, https://www.facebook. com/OpiekunOsobyNiepelnosprawnej, dostęp 10.01.2016. 
osobą niepełnosprawną po ukończeniu przez nią wieku określonego w tym przepisie ze względu na moment powstania niepełnosprawności jest niezgodne z konstytucją ${ }^{27}$, projekt nowelizacji z marca $2015 \mathrm{r}$. został bowiem, oficjalnie ze względu dużą liczbę krytycznych uwag zgłaszanych w konsultacjach, zawieszony, a nowych rozwiązań nie wypracowano. Również nowy rząd powołany jesienią 2015 r. dotychczas (luty 2016) nie ogłosił żadnych konkretnych rozwiązań, a jedynie zapewnił, że prace nad realizacją wyroku trwają.

Próbując podsumować całą sytuację, można zauważyć, że dopóki media interesowały się problemem, a środowisko - przynajmniej z perspektywy odbioru społecznego - nie było podzielone i w jasny sposób komunikowało swoje potrzeby, dopóty odnosiło sukcesy. Rozciągnięcie całego procesu w czasie i zwiększenie liczby tematów ograniczyło możliwości śledzenia dyskusji - do czego przysłużył się także brak informacji o przebiegu całego procesu ze strony rządowej - oraz znacznie zwiększyło liczbę różnych interesariuszy, a tym samym ograniczyło możliwość wypracowania wspólnego stanowiska.

\section{Społeczny raport alternatywny z realizacji konwencji o prawach osób z niepełnosprawnościami ${ }^{28}$}

Szerokie forum organizacji pozarządowych związanych ze środowiskiem osób niepełnosprawnych i współpracujących z nimi ekspertów wyszło z pomysłem przygotowania alternatywnego raportu wobec raportów przygotowanych przez rząd i Rzecznika Praw Obywatelskich dotyczących wdrażania KPON. Wersja rządowa miała się skupić na opisie prawa, bez pokazywania problemów i tego, na ile prawo jest zgodne z praktyką. Natomiast opracowanie RPO omawiało wybrane artykuły, o których można było coś powiedzieć na podstawie danych zastanych. Stąd organizacje pozarządowe zgłosiły ideę, by uzupełnić ten obraz o problemy występujące w praktyce, wyzwania wraz z omówieniem wszystkich artykułów prawnych. Chodziło o to, aby odpowiedzieć na pytanie, w jaki sposób artykuły KPON są wdrażane w Polsce, a w szczególności wskazać, w jakich obszarach nie są stosowane.

Grupą inicjatywną były osoby skupione w grupie ekspertów ds. osób z niepełnosprawnością przy Rzeczniku Praw Obywatelskich, które już wcześniej zajmowały

27 Zob. Prawo do świadczenia pielęnacyjnego, http://trybunal.gov.pl/rozprawy/komunikaty-prasowe/ komunikaty-po/art/7169-prawo-do-swiadczenia-pielegnacyjnego, dostęp 19.01.2016.

${ }^{28}$ Wszystkie informacje o projekcie i przygotowaniach raportu dostępne w: Raport $z$ realizacji Konwencji o prawach osób niepetnosprawnych, http://konwencja.org, dostęp 19.01.2016. 
się tematyką konwencyjnąą . Jednocześnie od początku postawiono sobie za cel, by w przygotowanie raportu włączyło się jak najwięcej osób w roli autorów poszczególnych artykułów, uczestników konsultacji, jak też poprzez wyrażenie opinii o treści i rekomendacji zawartych w ostatecznej wersji raportu.

Ostatecznie raport alternatywny z wdrażania w Polsce KPON został opracowany w okresie od września 2014 do czerwca 2015 r. Odbyło się wówczas 12 spotkań rady projektu, 10 paneli eksperckich, pięć spotkań konsultacyjnych (Łódź, Warszawa, Gdynia, Wrocław, Kraków) oraz konferencja podsumowująca w Warszawie. Poszczególne artykuły zostały napisane przez 20 autorów, a skonsultowane i uzupełnione przez niemal 250 osób, natomiast cały raport został poparty przez kilkadziesiąt organizacji pozarządowych działających na rzecz osób z niepełnosprawnościami. Warto też podkreślić fakt, że całość projektu była prowadzona zgodnie z zasadami uniwersalnej dostępności ${ }^{30}$, a sam raport został uzupełniony o wersję łatwą do czytaniu przez osoby z niepełnosprawnością intelektualną, jak i w polskim języku migowym dla osób głuchych ${ }^{31}$. Kontynuację prowadzonych działań stanowią: przygotowywanie planowanego na wrzesień 2016 r. II Kongresu Osób z Niepełnosprawnościami ${ }^{32}$, a także próby zainteresowania nowych władz RP zgłoszonymi w raporcie postulatami oraz podjęcia dyskusji na ich temat ${ }^{33}$.

Raport ten, podobnie jak raport rządowy czy opracowanie RPO, nie przebił się do głównego nurtu debaty publicznej oraz mediów, zresztą jak sama KPON, która jest przede wszystkim znana specjalistom zajmującym się tą tematyką. Nie ma też żadnych podstaw do twierdzenia, że zgłoszone postulaty stały się priorytetami dla rządu i są powszechnie wykorzystywane w dyskursie. Siłą projektu jest raczej mobilizacja i integracja środowiska pozarządowego, a także możliwość wymiany poglądów.

Być może jedna z przyczyn ograniczonego wpływu raportu tkwiła w poruszanej problematyce, czyli próbie całościowego spojrzenia na zjawisko niepełnosprawności i osób z niepełnosprawnościami. We wcześniej omawianym przypadku, tzn. dodatkowych wag subwencyjnych, zagadnienie było znacznie łatwiejsze do przedstawienia

${ }_{29}$ Zob. O projekcie, http://konwencja.org/o-projekcie, dostęp 19.01.2016. Projekt Raport z realizacji Konwencji o prawach osób z niepetnosprawnościami, realizowany ze środków programu „Obywatele dla demokracji”, którego operatorem były Fundacja im. Stefana Batorego i Polska Fundacja Dzieci i Młodzieży.

${ }^{30}$ Zaczynając od spełniającej standard WCAG 2.0 na poziomie AA strony internetowej, poprzez organizację spotkań w lokalach bez barier architektonicznych, z zapewnieniem pętli indukcyjnej dla osób niedosłyszących, na przygotowywaniu materiałów do konsultacji w polskim języku migowym kończąc.

${ }^{31}$ Zob. Cała treść raportu, http://konwencja.org/cala-tresc-raportu, dostęp 19.01.2016.

32 Zob. Rozpoczynamy pracę nad II Kongresem Osób z Niepełnosprawnościami!, http://konwencja. org/uncategorized/rozpoczynamy-prace-nad-ii-kongresem-osob-z-niepelnosprawnosciami, dostęp 19.01.2016.

${ }_{33}$ Zob. List do prezydenta RP, http://konwencja.org/uncategorized/list-do-prezdenta-rp, dostęp 19.01.2016. 
i późniejszego nagłośnienia w mediach, co ułatwiało włączenie problematyki do głównego nurtu. Można natomiast dostrzec pewne podobieństwo do protestu opiekunów osób z niepełnosprawnościami, który w mediach został ograniczony do jednego problemu wiodącego - podniesienia świadczenia pielęgnacyjnego, co, moim zdaniem, pozwoliło na osiągnięcie sukcesu. Za to będący już kontynuacją protestu tzw. okrągły stół, starając się objąć całość problematyki, błyskawicznie stracił na medialnym znaczeniu i został zakończony bez sformułowania żadnych konkluzji. Wskazuje to na dosyć istotną barierę dotyczącą bardziej systemowych zmian polityki wobec niepełnosprawności związaną z niemożnością/trudnością uproszczenia przekazu, tak by był zrozumiały dla wszystkich aktorów i - co chyba równie ważne - postronnych obserwatorów całego procesu.

Wszystkie powyższe przypadki, niezależnie od skali proponowanych zmian, rozmachu działań i osiągniętego rezultatu, łączy podobna ścieżka postępowania. Punktem startu jest chęć dokonania zmiany w polityce publicznej, najczęściej w wyniku osobistej motywacji - czy to osób z niepełnosprawnościami, czy opiekunów. Kolejnym elementem działania jest zasygnalizowanie problemu przedstawicielom władzy, którzy najczęściej bagatelizują bądź ignorują jego istnienie. Stąd potrzeba zebrania dowodów - jak w przypadku zamiany subwencji w dotację - oraz sojuszników, by uwiarygodnić oraz wzmocnić swój głos. Nieodzownym elementem nagłośnienia danej kwestii jest udział mediów, które mogą wymusić zainteresowanie polityków, oraz przydatne argumenty merytoryczne oparte na dowodach. Inaczej mówiąc: dochodzi wówczas do wpłynięcia na agendę, czyli odbywa się proces definiowania problemów publicznych.

Jednocześnie media, choć potrafią zareagować błyskawicznie i w bardzo szybkim tempie nagłośnić daną kwestię, równie szybko - czego przykładem są świadczenia pielęgnacyjne - mogą stracić zainteresowanie tematem. Można zatem bez większego ryzyka postawić tezę, że choć na etapie formowania agendy media są istotniejsze, to po nagłośnieniu problemu bardziej kluczowe stają się argumenty merytoryczne, wykorzystywane $\mathrm{w}$ procesie deliberacji, $\mathrm{w}$ tym gotowe propozycje rozwiązań legislacyjnych. Ważne jest także stałe podtrzymywanie zainteresowania mediów problemem, do czego potrzebne są dobre kontakty z dziennikarzami i „świeże” informacje o problemie, czyli w przypadku zamiany subwencji w dotację - monitoring edukacji włączającej i kolejne przykłady nieprawidłowości. Przyjęte rozwiązania bądź decyzja o ich braku, co także jest wyborem politycznym, to wypadkowa nacisków poszczególnych grup interesu oraz zainteresowania mediów. 
Warto także zwrócić uwagę na specyficzny przypadek protestu opiekunów dzieci z niepełnosprawnościami, gdy głównym powodem szybkiego wprowadzenia nowelizacji ustawy o zmianie ustawy o świadczeniach rodzinnych była chęć zdjęcia tematu z agendy i przy okazji skoncentrowanie się jedynie na głównym wątku, jakim była podwyżka świadczeń pielęgnacyjnych, przy wygaszeniu pozostałych tematów w ramach prac okrągłego stołu ds. niepełnosprawności. W odniesieniu do prób zamiany subwencji w dotację, choć nie osiągnięto ostatecznie pełnego sukcesu, niejako przy okazji wpłynięto na szereg innych rozwiązań związanych z edukacją włączającą i dyskurs związany z edukacją uczniów z niepełnosprawnościami w szkołach ogólnodostępnych. $\mathrm{W}$ przypadku raportu społecznego $\mathrm{z}$ wdrażania KPON pełni on przede wszystkim rolę syntetycznego źródła wiedzy o problemach osób z niepełnosprawnościami i ma charakter drugorzędny, ale jego powstanie pomogło w integracji środowiska organizacji działających na rzecz osób z niepełnosprawnościami oraz uwspólnianiu - przynajmniej do pewnego stopnia - stanowisk, co przy tak dużej różnorodności celów i problemów specyficznych dla poszczególnych niepełnosprawności nie jest sprawą oczywistą. Jednocześnie na bazie tej inicjatywy powstał zespół ekspercki, który współpracuje obecnie przy innych projektach.

Podsumowując, należy stwierdzić, że działania obywateli, choć niekoniecznie przynoszą pożądany skutek, wywierają pewien wpływ na politykę publiczną wobec osób z niepełnosprawnościami, przy całej świadomości, że obywatele nie są tutaj - i pewnie długo nie będą - kluczowymi aktorami. Jednak ich największą zaletą jest integracja środowiska i wzmacnianie roli aktorów społecznych, a tym samym budowanie potencjału na przyszłość.

\section{Bibliografia}

Al-Khamisy D., Edukacja włączająca edukacją dialogu: w poszukiwaniu modelu edukacji dla ucznia ze specjalnymi potrzebami edukacyjnymi, Wydawnictwo Akademii Pedagogiki Specjalnej, Warszawa 2013.

Bakalarczyk R., Polityka wsparcia rodzin z osobami niepełnosprawnymi. W cieniu wyroków Trybunału Konstytucyjnego RP i protestów społecznych, „Studia z Polityki Publicznej” 2015, nr 1(5), s. 63-80.

Bakalarczyk R., Kubicki P., Polakowski M., Szelewa D., Niepełnosprawność: problemy opieki. Warszawskie debaty o polityce społecznej 15, Friedrich-Ebert-Stiftung, Przedstawicielstwo w Polsce wspólnie z Fundacją Międzynarodowe Centrum Badań i Analiz (ICRA), Warszawa 2015.

Cairney P., Understanding public policy: theories and issues, Palgrave Macmillan, New York 2012. 
Dudzińska A., Wszystko jasne. Dostępność i jakość edukacji dla uczniów z niepełnosprawnościami. Raport końcowy z realizacji projektu, Stowarzyszenie Pomocy Dzieciom z Ukrytymi Niepełnosprawnościami im. Hansa Aspergera „Nie-Grzeczne Dzieci”, Warszawa 2009.

Grewiński M., Wielosektorowa polityka społeczna: o przeobrażeniach państwa opiekuńczego, Wydawnictwo Wyższej Szkoły Pedagogicznej TWP, Warszawa 2009.

Howlett M., Designing public policies: principles and instruments, Routledge, New York 2011.

Kloskowska-Dudzińska A., System zamknięty: socjologiczna analiza procesu legislacyjnego, Wydawnictwo Naukowe Scholar, Instytut Studiów Politycznych Polskiej Akademii Nauk, Warszawa 2015.

Kubicki P., Prawne bariery edukacji właczajacej, „Studia Prawnicze” 2013, z. 2(194), s. 63-77.

Kubicki P., Równy dostęp do edukacji osób z niepetnosprawnościami, „Biuletyn RPO. Źródła” 2012, nr 10, s. 34-40.

Kurowski K., Wolności i prawa człowieka i obywatela z perspektywy osób z niepełnosprawnościami, Biuro Rzecznika Praw Obywatelskich, Warszawa 2014.

Szarfenberg R., Potrzeba udziału obywateli $w$ tworzeniu, realizacji i doskonaleniu polityki spoŁecznej, Konferencja EAPN „Partycypacja obywatelska w tworzeniu usług społecznych”, Warszawa, 15 stycznia 2016.

Vanhala L., Making Rights a Reality?: Disability Rights Activists and Legal Mobilization, Cambridge University Press, Cambridge 2014.

Wpływ ruchu rodziców osób z niepełnosprawnościa intelektualna na rozwój nauki i życie społeczne: raport $z$ badań, red. B. Abramowska, Polskie Stowarzyszenie na rzecz Osób z Upośledzeniem Umysłowym, Warszawa 2014.

Zybała A., Polityki publiczne: doświadczenia w tworzeniu i wykonywaniu programów publicznych $w$ Polsce i w innych krajach. Jak działa państwo, gdy zamierza (chce) musi rozwiązać zbiorowe problemy swoich obywateli?, Krajowa Szkoła Administracji Publicznej, Warszawa 2012. 